\title{
ANALISIS PROSES PEMBELAJARAN MATEMATIKA PADA ANAK BERKEBUTUHAN KHUSUS (ABK) DI KELAS INKLUSI SMA NEGERI 10 KOTA TERNATE
}

\section{ANALYSIS OF MATHEMATICAL LEARNING PROCESSES FOR SPECIAL NEEDS STUDENTS IN INCLUSIVE CLASS OF SMA NEGERI 10 KOTA TERNATE}

\author{
Ariestha Widyastuty Bustan ${ }^{a}$, Rauman Mahmud ${ }^{b}$ \\ a Program Studi Matematika FMIPA Universitas Pasifik Morotai \\ Jl. Siswa Darame, Kecamatan Morotai Selatan Kabupaten Pulau Morotai \\ Provinsi Maluku Utara, ariesthawidyastutybustan@gmail.com \\ b Program Studi Matematika FMIPA Universitas Pasifik Morotai \\ J1. Siswa Darame, Kecamatan Morotai Selatan Kabupaten Pulau Morotai \\ Provinsi Maluku Utara, raumanmahmud01@gmail.com
}

\begin{abstract}
ABSTRAK
Penelitian ini bertujuan untuk mengetahui bagaimana proses pembelajaran matematika pada anak berkebutuhan khusus yang melibatkan persiapan guru sebelum proses pembelajaran, pelaksanaan pembelajaran dan evaluasi selama proses pembelajaran matematika di kelas inklusif SMA Negeri 10 Kota Ternate. Penelitian ini adalah penelitian deskriptif kualitatif. Jenis penelitian yang digunakan adalah jenis penelitian lapangan dengan teknik pengumpulan data melalui observasi, wawancara dan dokumentasi. Subjek penelitian dalam penelitian ini adalah guru matematika di kelas inklusif. Teknik analisis data yang digunakan dalam penelitian ini adalah pengumpulan data, reduksi data, penyajian data, penarikan kesimpulan, dan verifikasi. Validasi data menggunakan teknik triangulasi waktu. Hasil penelitian menunjukkan bahwa beberapa hal adalah sebagai berikut: (1) Sebelum proses pembelajaran matematika berlangsung, subjek menyiapkan rencana pelajaran, silabus, media dan sumber belajar namun masih belum ada yang spesifik untuk siswa berkebutuhan khusus, (2) Subjek mempersiapkan siswa secara psikologis dan fisik, mengajukan pertanyaan pengantar dan mengulang konsep matematika dasar. Subjek membentuk kelompok yang menggabungkan siswa berkebutuhan khusus dan siswa normal dalam satu kelompok, (3) Subjek mengambil inisiatif untuk bertanya langsung kepada siswa berkebutuhan khusus bagian mana dari materi yang belum dipahami.
\end{abstract}

Kata Kunci: ABK, pembelajaran matematika, Pendidikan inklusi, sekolah inklusi.

\begin{abstract}
This study aims to find out how the learning process of mathematics in disabilities of unsociable and slow learners which involved teacher preparation before the learning process, implementation of learning and follow-up the evaluation as well as what are the barriers faced by special needs students during the learning process of mathematics in inclusive class of SMA Negeri 10 Kota Ternate. This study is a qualitative descriptive study. The type of study used is a type of field study with data collection techniques through observation, interviews and documentation. The research subjects in this study were mathematics teachers in inclusive class. The data analysis technique used in this study were data collection, data reduction, data presentation, conclusions, and verification. Data validation uses time triangulation technique. The results of the study show that several things are as follows: (1) Before mathematics learning process took place, the subject prepared lesson plan, syllabus, media and learning resources however there was not still specific for special needs students, (2) Subject prepared students psychologically and physically, asked introductory questions and
\end{abstract}


repeated basic mathematics concept. The subject made a group that combined special needs students and normal students in one group, (3) Subject took the initiative to ask directly to the special needs students which parts of the material were not understood yet.

Keywords: special needs students, learning process of mathematics, inclusive education, inclusive school.

\section{Pendahuluan}

Pendidikan berlaku bagi seluruh peserta didik tanpa menyertakan diskriminasi terhadap faktor apapun. Setiap anak memiliki kesempatan yang sama untuk memperoleh fasilitas pendidikan secara optimal, tak terkecuali bagi Anak Berkebutuhan Khusus (ABK). Salah satu upaya pemerintah untuk melakukan pemerataan pendidkan bagi $\mathrm{ABK}$ adalah dengan menjalankan program pendidikan inklusi yang dilaksanakan di sekolah-sekolah inklusi. Sekolah inklusi adalah sekolah reguler yang mengkolaborasikan pendidikan khusus dan pendidikan reguler dalam satu system.

SMA Negeri 10 Kota Ternate adalah salah satu sekolah di Kota Ternate yang menyelenggarakan pendidikan inklusi sejak tahun 2008. Meskipun belum memiliki Guru Pendamping Khusus (GPK), setiap tahunnya secara rutin guru-guru mata palajaran secara bergantian diutus oleh pihak sekolah untuk mengikuti kegiatan pelatihan dari Direktorat Pembinaan Pendidikan Khusus dan Layanan Khusus (PKLK) maupun Dinas Pendidikan dan Pengajaran (Dikjar) Setempat. Oleh

Analisis... (Ariestha) karena itu semua guru mata pelajaran yang menangani kelas inklusi sudah dibekali pengetahuan tentang penanganan siswa $\mathrm{ABK}$ saat proses pembelajaran. Selain guru mata pelajaran, wali kelas dan konselor sekolah juga turut mendampingi siswa ABK selama proses pembelajaran dalam kondisi-kondisi tertentu.

Anak kebutuhan khusus merupakan anak yang signifikan mengalami penyimpangan ataupun kelainan baik secara fisik, mental-intelektual, sosial, dan emosional dalam proses pertumbuhan dan atau perkembangannya dibandingkan dengan anak-anak lain seusianya sehingga mereka memerlukan pelayanan pendidikan khusus (Hermanto, 2008:9).

Berdasarkan proses wawancara dengan guru mata pelajaran dan konselor sekolah, saat ini ABK yang sedang melangsungkan pendidikan disana berjumlah 16 siswa dan ada 3 kelas yang di dalamnya terdapat dua jenis kebutuhan khusus sekaligus, yaitu tunalaras dan lamban belajar.

$$
\text { Menurut Budyartati }
$$
tunalaras adalah anak yang mengalami kesulitan dalam penyesuaian diri dan 
bertingkah laku tidak sesuai dengan normanorma yang berlaku dalam kehidupan bermasyarakat pada umumnya. Sedangkan Slow leaner atau lamban belajar adalah seseorang yang memiliki intelegensi sedikit di bawah intelegensi normal, namun tidak termasuk dalam seorang tunagrahita, ratarata seorang lamban belajar memiliki IQ diantara 80 sampai 85 (Cahya, 2014:21).

Penelitian dengan tema yang sama pernah dilakukan oleh Irawan dan Febriyanti (2018:99), Rahmawati, Sujadi, dan Subanti (2018:1), dan Hadi (2014:1). Irawan dan Febriyanti dalam hasil penelitiannya menyebutkan bahwa ABK Autis pada kategori rendah dan sedang dapat mengikuti proses pembelajaran di kelas inklusi dan untuk pembelajaran matematika yang diberikan di kelas, tingkat kesulitan untuk materi matematika lebih rendah dibandingkan tingkat kesulitan materi matematika yang diberikan kepada siswa non ABK. Rahmawati, Sujadi dan Subanti mengatakan bahwa dalam mempersiapkan proses pembelajaran matematika guru mata pelajaran dan GPK berdiskusi terlebih dahulu untuk menyiapkan materi yang akan dipelajari siswa $\mathrm{ABK}$, khususnya $\mathrm{ABK}$ tunagrahita.

Rumusan masalah dalam penelitian ini adalah "Bagaimana proses pembelajaran matematika pada ABK Tunalaras dan lamban belajar yang meliputi kesiapan guru sebelum proses pembelajaran, pelaksanaan pembelajaran dan evaluasi tindak lanjut?" Penelitian ini berbeda dengan penelitian yang relevan sebelumnya, karena menganalisis proses pembelajaran pada dua jenis ABK sekaligus dalam suatu kelas inklusi, yaitu ABK lamban belajar dan tunalaras.

\section{Metode Penelitian}

\section{Waktu dan Tempat Penelitian}

Penelitian ini dilaksanakan di SMA N 10 Kota Ternate selama 6 bulan. Waktu pelaksanaan kegiatan direncanakan dimulai dari bulan April 2019 sampai bulan September 2019.

\section{Tipe Penelitian}

Penelitian ini merupakan penelitian deskriptif dengan pendekatan penelitian yang digunakan adalah pendekatan kualitatif. Jenis penelitian yang digunakan adalah jenis penelitian lapangan (field research).

\section{Subjek Penelitian}

Pemilihan subjek menggunakan teknik Purposive Sampling, dengan kata lain subjek penelitian ditentukan berdasarkan pertimbangan secara tidak acak guna bisa mencapai tujuan penelitian. Subyek penelitian yang digunakan adalah guru mata 
pelajaran matematika. Hal tersebut dikarenakan subjek penelitian yang dipilih adalah subjek yang berhubungan langsung dengan kegiatan pembelajaran matematika, dan mengetahui betul kondisi para siswanya termasuk siswa ABK itu sendiri.

\section{Prosedur Penelitian}

Penelitian ini akan dilaksanakan dalam 4 tahap dan pada setiap akhir tahapan penelitian tim peneliti akan melakukan evaluasi untuk kelancaran proses penelitian. Berikut uraian kelima tahapan tersebut.

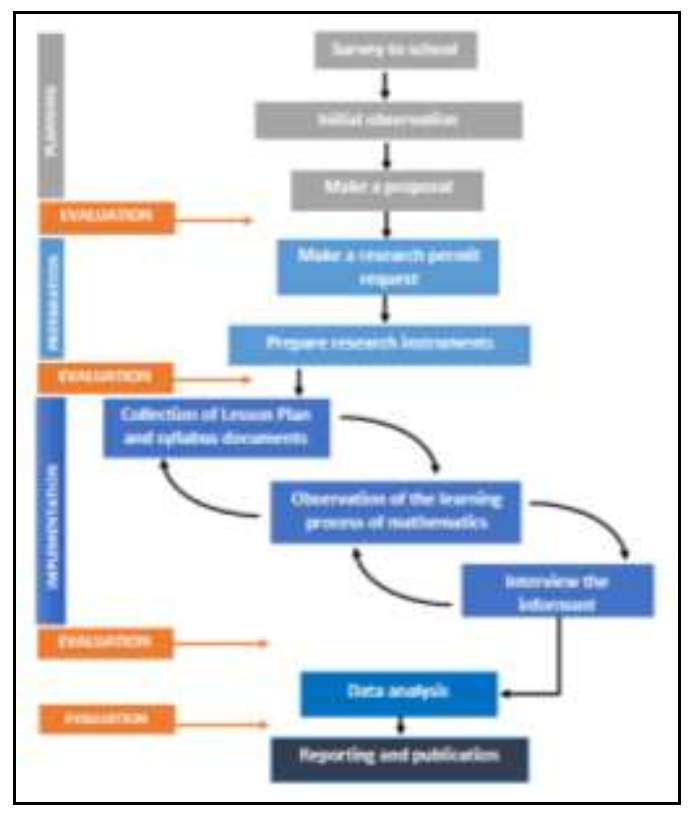

Gambar1. Prosedur Penelitian

\section{Teknik Pengumpulan Data}

Teknik pengumpulan data dilakukan melalui kegiatan observasi, wawancara dan dokumentasi terhadap proses pembelajaran matematika ABK di kelas inklusi SMA N 10 Kota Ternate. Kegiatan observasi dilakukan oleh peneliti terhadap proses pembelajaran matematika meliputi kesiapan guru mata pelajaran sebelum proses pembelajaran, pelaksanaan pembelajaran dan evaluasi tindak lanjut. Selanjutnya peneliti akan melakukan wawancara kepada subjek penelitian guna mengetahui lebih detail apa saja kendala-kendala yang dihadapi ABK saat proses pembelajaran matematika disertai penyelesaiannya. Selain itu akan dilakukan analisis terhadap dokumen-dokumen pendukung seperti RPP dan dokumen kurikulum.

\section{Instrumen Penelitian}

Instrumen dalam penelitian ini terdiri dari instrument utama dan instrument bantu. Instrumen utama adalah peneliti sendiri yang secara langsung mengumpulkan berbagai data dari sumber data. Sedangkan instrumen bantu yang digunakan meliputi lembar observasi dan pedoman wawancara.

\section{Validitas Data}

Teknik validasi data yang digunakan dalam penelitian ini adalah teknik triangulasi. Jenis triangulasi yang digunakan dalam penelitian ini adalah triangulasi waktu, dimana peneliti mengecek keabsahan data dari sumber yang sama dalam waktu yang berbeda-beda. Data hasil observasi yang diperoleh dari guru mata pelajaran matematika.

\section{Teknik Analisis Data}


Teknik analisis data yang digunakan dalam penelitian ini adalah pengumpulan data, reduksi data, penyajian data, penarikan kesimpulan, dan verifikasi.

\section{Hasil dan Pembahasan}

\section{Kesiapan guru sebelum proses pembelajaran}

Sebelum proses pembelajaran matematika berlangsung subjek menyiapkan RPP dan silabus namun belum ada lesson plan dan silabus untuk siswa berkebutuhan khusus tunalaras maupun siswa berkebutuhan khusus lamban belajar. Subjek juga menyiapkan media dan sumber belajar namun belum ada media khusus untuk ABK.

\section{Proses pembelajaran}

\section{a. Pendahuluan}

Subjek menyiapkan siswa secara psikis maupun fisik seperti mengecek alat tulis, berdoa dan mengecek kehadiran siswa. Subjek mengajukan pertanyaanpertanyaan pengantar dan mengulangi materi-materi matematika dasar atau materi sebelumnya yang berkaitan dengan materi yang akan dipelajari. Pertanyaan dan pengulangan materi berlaku untuk siswa ABK maupun non ABK. Subjek menjelaskan tujuan pembelajaran dan kompetensi yang dicapai sebelum dimulai.

b. Kegiatan Inti pembelajaran Subjek menggunakan media dan sumber belajar (buku) sesuai dengan yang ada pada RPP materi matematika yang diajarkan dan melibatkan siswa ABK maupun non ABK dalam proses pembelajaran. Subjek membuat kelompok yang menggabungkan antara siswa $\mathrm{ABK}$ dan non ABK dalam satu kelompok untuk memfasilitasi interaksi antara siswa ABK dan non $\mathrm{ABK}$, dan berlaku pula antara siswa ABK Tunalaras dan ABK slow learner. Subjek melakukan pemberian tugas yang berlaku untuk seluruh siswa dan memantau serta membimbing proses pembelajaran.

\section{c. Penutup}

Subjek melibatkan semua siswa di dalam kelas untuk membuat kesimpulan pembelajaran. Penilaian dilakukan secara tertulis melalui tes atau tugas, dimana standar penilaian untuk siswa ABK diturunkan dari segi standar soal dan jumlah soal. Umpan balik yang dilakukan dalam bentuk tanya jawab atau diskusi. Siswa abk slow learner atau abk tunalaras tidak bertanya meskipun tidak memahami materi yang diajarkan, oleh karena itu 
subjek mengambil inisiatif untuk bertanya sendiri kepada siswa ABK tersebut.

\section{Evaluasi dan tindak lanjut}

Kegiatan yang dilakukan setelah proses pembelajaran berlangsung adalah adalah pemberian tugas dan penyampaian materi untuk pertemuan selanjutnya. Kegiatan tindak lanjut yang dilakukan setelah proses pembelajaran hanya berupa remedial, sedangkan pengayaan dan bimbingan konseling bersifat insidensial (hanya dilakukan pada saat dibutuhkan).

\section{Kesimpulan}

Sebelum proses pembelajaran matematika berlangsung, subjek menyiapkan rencana pelajaran, silabus, media dan sumber belajar tetapi masih belum spesifik untuk siswa berkebutuhan khusus. Subjek mempersiapkan siswa secara psikis dan fisik, mengajukan pertanyaan pengantar dan mengulang konsep matematika dasar. Subjek membuat kelompok yang menggabungkan siswa berkebutuhan khusus dan siswa normal dalam satu kelompok. Subjek melibatkan semua siswa di kelas untuk menarik kesimpulan pembelajaran. Umpan balik dilakukan dalam bentuk tanya jawab atau diskusi. Siswa lambat belajar dan tunalaras tidak mengajukan pertanyaan meskipun mereka tidak mengerti materi yang diajarkan, oleh karena itu subjek mengambil inisiatif untuk bertanya langsung kepada siswa berkebutuhan khusus bagian mana dari materi yang belum dipahami. Dalam mengajarkan konsep matematika dasar untuk siswa berkebutuhan khusus, subjek melakukannya dengan lebih lambat dan sering diulang. Siswa berkebutuhan khusus cepat bosan mengikuti proses belajar matematika, oleh karena itu subjek membuat kelompok, sehingga siswa berkebutuhan khusus dapat berinteraksi dengan siswa normal. Kegiatan tindak lanjut yang dilakukan setelah proses pembelajaran hanya berupa remedial, sedangkan pengayaan dan bimbingan konseling bersifat insidensial

\section{Ucapan Terimakasih}

Terimakasih kami kepada DPRM Kemenristek Dikti yang telah memfasilitasi pembiayaan terhadap penelitian dengan skema Penelitian Dosen Pemula yang berjudul "Analisis Proses Pembelajaran Matematika pada Anak Berkebutuhan Khusus (ABK) di Kelas Inklusi SMA Negeri 10 Kota Ternate", tahun pembiayaan 2019 dengan nomor kontrak 118/SP2H/LT/DPRM/2019. Selanjutnya terimakasih kepada LPPM Universitas Pasifik morotai yang telah memfasilitasi pelaksanaan penelitian ini. 


\section{Pustaka}

Budyartati, S, 2014, Problematika Pembelajaran di Sekolah Dasar Ed 1, Yogyakarta: Deep Publish.

Cahya, L, S, 2014, Adakah ABK di Kelasku, Bagaimana Guru Mengenali ABK di Sekolah, Yogyakarta: Dianda Kreatif.

Hadi, F, R, 2014, Analisis Proses Pembelajaran Matematika Pada Anak Berkebutuhan Khusus (ABK) Slow Learners Di Kelas Inklusi (Penelitian Dilakukan di SD Al Firdaus Surakarta) Doctoral dissertation, UNS (eprints.uns.ac.id/21550/).

Hermanto, H, 2008, Kemampuan guru dalam melakukan identifikasi anak berkebutuhan khusus di sekolah dasar penyelenggara pendidikan inklusi, Yogyakarta:Yogyakarta State University.

Irawan, A., Febriyanti, C. 2018, Pembelajaran Matematika pada Siswa Berkebutuhan Khusus di Sekolah Inklusi J. Medives J. Math. Educ. IKIP Veteran Semarang 2(1):99.

Rahmawati, F., Sujadi, I., Subanti, S, 2016, Analisis Proses Pembelajaran Matematika Anak Berkebutuhan Khusus (ABK) Tunagrahita pada Materi Peluang di Kelas Inklusi SMA Al Firdaus Surakarta Tahun Ajaran 2015/2016 UNS-Pascasarjana Prog. Studi Magister Pendidikan Matematika-S.851502008-2016 
